\title{
THE ROLE OF ECONOMIC INTEGRATION FOR THE FUNCTIONING OF POLISH AGRICULTURAL SECTOR ON THE EXAMPLE OF THE RURAL DEVELOPMENT PROGRAM (RDP)
}

\author{
Sebastian Stepień ${ }^{1}$ \\ Jan Polcyn ${ }^{2}$
}

\begin{abstract}
The aim of the paper is to evaluate the Rural Development Program (as a part of Common Agricultural Policy of the EU) from the point of view of impact on the agri-food sector in Poland. An introduction to the analysis is the identification of structural changes in Polish agriculture under the conditions of integration with the European Union. The following step consists in the assessment of the RDP for 2004-2006 and 2007-2013. The final stage is an evaluation of the rural support in the current financial perspective. It is clear from the considerations that the RDP first set up the multiplying effects of investment expenditure (under modernization programs), thus increasing the efficiency of the use of production factors (mainly labor and land). Income support, in the form of funds for less-favored areas (and earlier as well as supplementary payments) has become an important accelerator of innovation, modernization and structural transformation processes in the countryside. The $R D P$ resources (including structural pensions) also served the expected transformations of the agrarian structure. Finally, part of the money was used to reduce excessive employment in the agricultural sector (diversification, micro-enterprise development). The article is an overview of the topic literature and statistical data, as well as previous studies of one of the authors. . It uses elements of descriptive analysis, meta-analysis and deductive inference.
\end{abstract}

Key words: Rural Development Programme, agricultural sector, influence, structural changes, Poland.

JEL codes:Q10, Q18, R51, R58

\section{Introduction}

In May 2004, Poland was integrated into the structures of Common Agricultural Policy support (CAP). The previously functioning intervention mechanisms in the food market were changed, and substantial EU funds were invested in the domestic agricultural sector and rural areas. Overall, in $2004-2013^{3}$ the beneficiaries of this policy were paid the amount of approximately PLN billion 210 within the framework of CAP, out of which the largest part of money was spent on direct subsidies (CAP 'first pillar'), which constituted almost $50 \%$ of the total support. The payments significantly supplemented the income of agricultural farms and were mainly used for ongoing production (purchase of fertilizers, feed, means of plant protection, seeds, etc.), whereas the pro-investment goals were achieved under the Rural Development Programme (RDP - CAP 'second pillar') funds for the years 20042006 and 2007-2013. These sources were also used for financing other activities, e.g. subsidies for less-favored areas (LFA), agri-environmental schemes, development of non-

\footnotetext{
${ }^{1}$ Poznań University of Economics and Business, Email: sebastian.stepien@ue.poznan.pl, Phone number: +4861 $8543017,+48696411391$

${ }^{2} \mathrm{PhD}$, Stanisław Staszic University of Applied Sciences in Piła, Email: jan.polcyn@ gmail.com, Phone number: +48605038566

${ }^{3}$ A part of the funds was also paid in the following two years on the basis of multi-annual agreements

DOI: 10.29302/oeconomica.2017.19.2.8
} 
agricultural business, or rural infrastructure. The amount of PLN billion 65 was spent on the above-mentioned programmes in 2004-2013, which constituted over 30\% of the total CAP support (including RDP for 2004-2006 - 5.2\%; RDP for 2007-2013 - 25.9\%). The remaining $20 \%$ of funds included e.g. market intervention, sectoral operational programme, common organization of the market in fruit and vegetables or fishing policy (Łykowski, 2015).

The second pillar of the Common Agricultural Policy is undoubtedly an element of support for Polish rural areas. Its significance results from the necessity to improve the agricultural structure in Poland, increase the competitiveness of agricultural producers, change the structure of employment and needs in the field of infrastructure development, or finally implement tasks related to the natural environment protection. Therefore, the amount of funds in RDP, as well as the structure of goals and their manner of implementation is key for the functioning of agriculture and the entire countryside in the perspective of many years to come. The purpose of the paper is to evaluate the Rural Development Programme from the point of view of impact on the agri-food sector in Poland. An introduction to the analysis is the identification of structural changes in Polish agriculture under the conditions of integration with the European Union. The subsequent conclusions concerning RDP for 20042006 and 2007-2013 will be presented. The final stage of the considerations is an evaluation of the rural support programme in the current financial perspective. This evaluation will be carried out in the following two areas: available budget resources and planned actions. The article is an overview of the topic literature and statistical data, as well as previous studies of one of the authors. . It uses elements of descriptive analysis, meta-analysis and deductive inference.

\section{Structural changes in Polish agriculture under the conditions of integration with the European Union - data review}

Integration with the European Union was both a challenge and an opportunity for more dynamic development for the agricultural sector. The challenge consisted in joining the European Single Market and the necessity of competing with the Western European countries (although as it turned out later, it was an impulse for creating export of Polish food), as well as adapting the national legislation to EU legislation with regard to quality, environmental and health standards, whereas the most important opportunity was definitely the possibility of using EU funds, including especially Common Agricultural Policy. The latter has a specific influence on transformation processes in the agricultural sector, because it is the only economic policy to have a complete Community character, based on uniform EU regulations and financed from the EU budget (Sadowski et al., 2013). There are many support instruments within the framework of CAP, both in the form of direct impact on the income value (e.g. direct subsidies in the first pillar), as well as indirect, requiring co-funding by agricultural producers (e.g. investment programmes in the second pillar). It can be assumed that the support itself is favorable for concentration processes in agriculture (both land and production), which is a result of the above-mentioned competition pressure in the integrated Europe and necessity to adapt to EU standards. Moreover, the employability potential for individuals who no longer want to stay in agriculture increases through financing activities related to creation of jobs outside agriculture. However, in certain conditions, a part of support instruments may consolidate the existing agricultural structures. This can be the case with direct subsidies for small farms, for which they are an element of income that is relatively easy to obtain and important. Another example can be modernization programmes with established upper limit of support that can lead to artificial division of farms in order to obtain funds (Czubak and Sadowski, 2011). However, structural changes in Polish agriculture are a fact, which will be evidenced by the below data. 
One of the symptoms of concentration processes occurring in the agricultural sector is the decrease of the number of farms, combined with an increase of their average size. While before the integration with EU their number amounted to almost 3 million $(2,933,000$ in 2002), 13 years later (in 2015) it fell to 1.4 million (decrease by 52\%). On the other hand, the average area of agricultural farm increased from 5.8 ha to 10.3 ha (increase by $78 \%$ ). These changes were mainly caused by the reduction of the number of units within the area group 0 4.99 ha (but also 5-9.99 and 10-19.99 ha), whereas the number of larger farms increased (compare table no. 1). The increase of middle-sized farms would be even higher, were it not for the fact that over 2.3 million ha of land was excluded from agricultural use in the period 2002-2016 and the current total agricultural area amounts to approximately 14.5 million ha (Central Statistical Office, 2017; Central Statistical Office 2011). It can be assumed that these exclusions concerned mostly the smallest agricultural farms, because the data indicate that during the same years the share of entities in the area group 0-5 ha in the total agricultural area fell from $16 \%$ to less than $13 \%$, whereas for the area group over 50 ha, it increased from 24 to $31 \%$. Despite these favorable changes, there is a need for further transformations, because in comparison with other EU countries (mainly EU-15) with similar structure of production, Poland looks less favorable (Sadowski et al., 2013; Central Statistical Office, 2017).

Table 1

Structure of farms in Poland in 2015 as compared to 2002

\begin{tabular}{|l|c|c|c|c|c|}
\hline \multicolumn{1}{|c|}{ Area group } & $\begin{array}{c}\text { Number of farms } \\
\text { (in thousands) in } \\
\mathbf{2 0 1 5}\end{array}$ & $\begin{array}{c}\text { Share } \\
\mathbf{( \% )}\end{array}$ & $\begin{array}{c}\text { Number of farms } \\
\text { (in thousands) in } \\
\mathbf{2 0 0 2}\end{array}$ & $\begin{array}{c}\text { Share } \\
(\mathbf{\%})\end{array}$ & $\begin{array}{c}\text { Number } \\
\text { change } \\
\mathbf{2 0 1 5 / 2 0 0 2}(\boldsymbol{\%})\end{array}$ \\
\hline $0-4.99$ ha & 735 & 52.1 & 2,124 & 72.4 & -65.4 \\
\hline 5-9.99 ha & 323 & 22.9 & 427 & 14.6 & -24.4 \\
\hline 10-19.99 ha & 217 & 15.4 & 266 & 9.1 & -18.4 \\
\hline $20-49.99$ ha & 102 & 7.3 & 96 & 3.3 & 6.3 \\
\hline $50-99.99$ ha & 22 & 1.6 & 17 & 0.6 & 29.4 \\
\hline $\begin{array}{l}100 \text { ha and } \\
\text { more }\end{array}$ & 11 & 0.8 & 3 & 0.1 & 266.7 \\
\hline Total & 1,410 & 100 & 2,933 & 100 & -51.9 \\
\hline
\end{tabular}

Source: Own study based on (Central Statistical Office, 2016; Central Statistical Office, 2011).

A result of the change of the number and average area of farms was an increase of concentration of both livestock and plant production (specific data were presented in table no. 2). Overall, in 2002-2015 the value of global livestock production increased by $22 \%$ (at constant prices from 2005), and the value of plant production increased by $30 \%$. The higher result for plant production can be a result of support orientation (including supplementary direct subsidies) towards this type of activity to a bigger extent that in case of livestock production (and therefore, in the perspective of 2014-2020, the support should be directed to livestock producers to a greater extent). As regards the changes in production structure, with reference to livestock, the share of poultry increased (from $31 \%$ to $46 \%$ of total production of slaughter animals in 2005-2015) in comparison with pigs (decrease from 54\% to 38\%), whereas the share of cattle production remained at a low level, although a slight increase was reported over the last several years. On the other hand, with reference to plant production, a decrease in the share of crops (from $74 \%$ to $70 \%$ of total sowings) and potatoes (from $2.5 \%$ to 
$1.7 \%$ ) was noted, whereas the increase concerned corn (from $6 \%$ to $11 \%$ ) and rapeseed (from $5 \%$ to $9 \%$ ) (Central Statistical Office, 2016).

Table 2

Change of stock density and sown area in Polish agricultural farms.

\begin{tabular}{|c|c|c|c|c|c|}
\hline \multirow{2}{*}{ Specification } & 2005 & 2007 & 2010 & 2013 & \multirow{2}{*}{$\begin{array}{l}\text { Change } \\
\text { 2013/2005 }\end{array}$} \\
\hline & \multicolumn{4}{|c|}{ Average animal herd per farm (items) } & \\
\hline Pigs & 25.3 & 27.9 & 39.2 & 40.6 & $60.8 \%$ \\
\hline Poultry & 114.8 & 123.3 & 256.0 & 259.3 & $126.0 \%$ \\
\hline \multirow[t]{2}{*}{ Cattle } & 7.0 & 8.2 & 11.2 & 13.9 & $98.3 \%$ \\
\hline & \multicolumn{4}{|c|}{ Average sown area per farm (ha) } & \\
\hline Crops & 4.9 & 5.0 & 6.4 & 6.7 & $36.1 \%$ \\
\hline Corn & 4.2 & 4.0 & 6.2 & 6.6 & $57.0 \%$ \\
\hline Sugar beet & 3.5 & 3.7 & 4.1 & 4.7 & $33.3 \%$ \\
\hline Rapeseed & 10.1 & 10.2 & 11.2 & 10.4 & $3.2 \%$ \\
\hline
\end{tabular}

Source: Own study based on Eurostat data, http://ec.europa.eu/eurostat/data/database.

The structural changes combined with the increase of support within the framework of Common Agricultural Policy led to improvement of economic results of farms in Poland. The average annual value of global production in 2004-2014 (at constant prices from 2005) amounted to PLN billion 72.0 and was $27 \%$ higher in comparison with the period 1999-2003, i.e. before Poland's accession to the EU. Despite the increase of real prices of expenditure for agriculture (by $18 \%$ in as compared to $5 \%$ increase of real prices of agricultural products), the average income level of a farm in 2004-2014 was almost 156\% higher in comparison with the pre-accession period. The key factor became EU subsidies for agriculture, which increased from the average income level of $9.3 \%$ in 1999-2003 to almost 50\% in the period after 2004 . At the same time, support within the framework of the second pillar increased the dynamics of investment, which grew to PLN 5.4 billion in 2014 compared with PLN 2.2 billion in 2002. The largest amounts were spent on buildings and structures, followed by machines and devices, as well as means of transport (figure 1). Thanks to the completed investments, the ratio of capital expenditure per working unit and land improved. On the average, in 20022004 the first index was approximately PLN 18,500/AWU ${ }^{4}$, the second - PLN 2,600/ha UR, whereas in 2014 the amounts were PLN 23,900/AWU and PLN 3,200 respectively. Moreover, the increased technical devices allowed to limit the total workload in the corresponding period from 2,280 AWU to 1,937 AWU (Baer-Nawrocka, Poczta, 2016).

\footnotetext{
${ }^{4}$ AWU - Annual Work Unit, jednostka przeliczeniowa rocznego czasu pracy. W polskim rolnictwie 1 AWU jest równoznaczne z nakładem 2120 godzin pracy rocznie. (AWU - Annual Work Unit, conversion unit of annual working time. In Polish agriculture, 1 AWU is equivalent to the expenditure of 2,120 annual working hours.)
} 


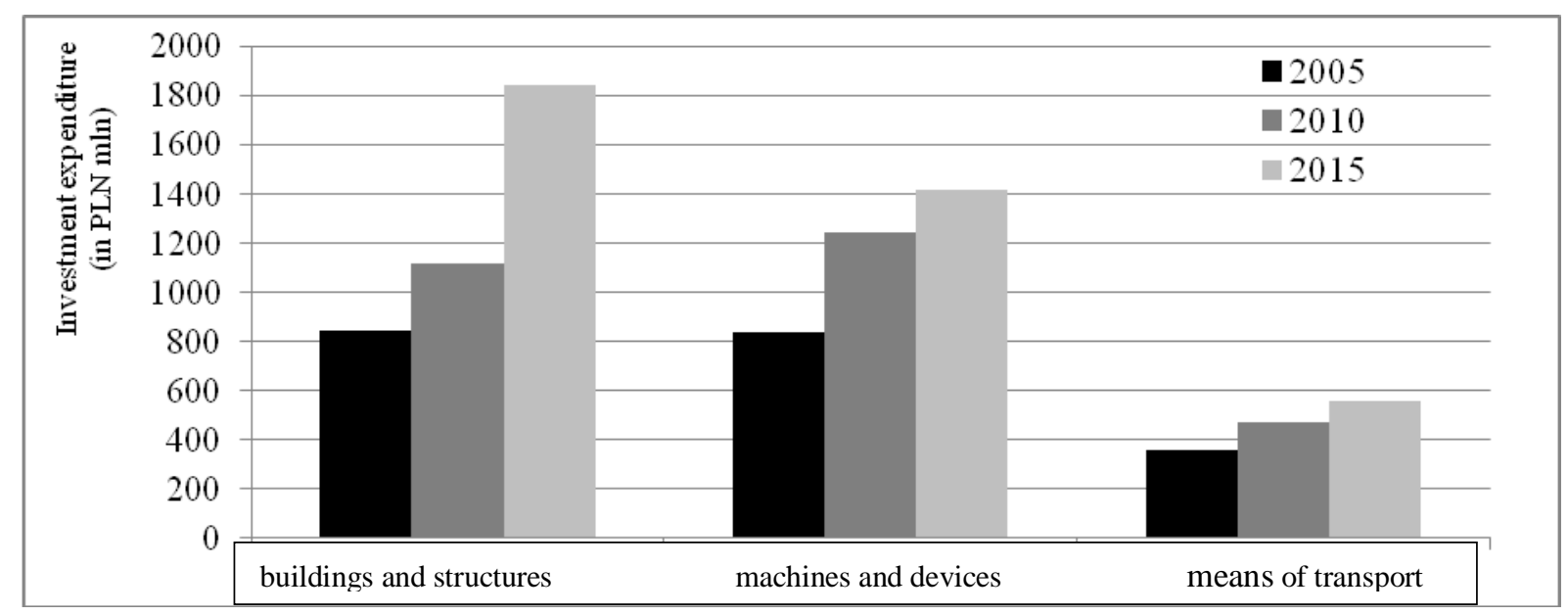

Figure no. 1. Investment expenditure in Polish agricultural farms (in PLN million; at constant prices 2005)

Source: Own study based on (Central Statistical Office, 2016; Central Statistical Office, 2011).

\section{Previous experiences with the Rural Development Programme}

The assessment of impact of RDP on structural changes in the Polish agriculture requires taking a closer look at the objectives and budgets of particular actions. And so, the total amount paid within the framework of RDP 2004-2006 was PLN 14.2 billion. Payments were made to the benefit of almost 926,000 beneficiaries. The largest share among all payments concerned the following tasks: 'Management in less-favored area' $(26.3 \%)$, 'Supplementary area payments' (18.9\%) and 'Adaptation of farms to the EU standards' (17.6\%). The first two had pro-income character and resulted in an increase of agricultural income. On the other hand, the third programme had an investment character and partly included expenses for pro-environmental objectives (adaptation in the field of organic fertilizer storage, i.e. construction of manure pads ${ }^{5}$ ). The three above-mentioned actions together stimulated the development of farms with regard to increase of agricultural area (also the status of set-aside lands decreased almost by $90 \%$ thanks to LFA), production scale, or modernization of manufacturing apparatus. On the other hand, the "Early retirement' programme (14.9\% of budget) was intended to transfer farms by individuals leaving work in agriculture because of age to younger farmers and, as such, to create units larger in size. The actual implementation of this programme led to transfer of 513,000 ha of agricultural area to the benefit of over 54,000 farmers (mainly under 40 years of age), thanks to which the acquiring individuals increased their farms (the percentage of acquiring farms under 5 ha after the acquisition decreased from $72 \%$ to $20 \%$, whereas the share of farms above 15 ha increased from $12 \%$ to over $32 \%$ ). However, on the other hand certain lack of coherence can be noticed in the assumptions of RDP for 2004-2006, because the help was also offered to small farms within the framework of 'Support for semi-subsistence farms' (9.5\% of budget), which could have consolidated the unfavorable agricultural structure ${ }^{6}$. This can be presumed e.g. from the numbers, according to which as much as $99.68 \%$ of farmers using the programme chose the support package intended for further conduct of agricultural activity (mainly purchase of agricultural machinery or livestock), whereby those were mainly small units with the surface

\footnotetext{
5 Environmental actions are also commonplace in the practice of non-agricultural enterprises (see also: Căpuşneanu et al., 2015).

${ }^{6}$ Among the remaining funds: 5.8\% was 'Support for projects and improvement of animal welfare', $3.3 \%$ SAPARD projects, $2.8 \%$ - 'Afforestation of agricultural land', $0.8 \%$ - 'Technical assistance', $0.2 \%$ - 'Groups of agricultural producers'.
} 
of 5-10 ha of agricultural area, while only $0.32 \%$ declared the willingness to begin nonagricultural activity (Klepacka, 2009).

RDP budget for 2007-2013 was significantly higher than the previous budget and amounted to PLN 74.3 billion, i.e. PLN 10.61 billion on average per year (in RDP for 20042006 it was PLN 4.73 billion on average per year). The amount was paid to over 1,184,000 beneficiaries within the framework of the following four axes: 'Improvement of competitiveness of the agricultural and forestry sector', 'Improvement of the environment and the countryside', 'Quality of life in rural areas and diversification of the rural economy' and 'LEADER' (PLN 1.1 billion was intended for technical assistance) (Ministry of Agriculture and Rural Development, 2015). The highest payments among the above-mentioned were made for the first axis, which shows that the programme is mostly oriented towards the development of farms.

Table 3

RDP budget for 2004-2006 and 2007-2013 divided into more important activities in favor of the agricultural sector (current prices)

\begin{tabular}{|l|r|r|l|r|r|}
\hline \multicolumn{2}{|l|}{$\begin{array}{l}\text { RDP budget for 2004-2006 } \\
\text { (in PLN billion) }\end{array}$} & Share & \multicolumn{2}{l|}{$\begin{array}{l}\text { RDP budget for 2007-2013 } \\
\text { (in PLN billion) }\end{array}$} & Share \\
\hline Total budget & $\begin{array}{r}14,212 . \\
5\end{array}$ & $100 \%$ & Total budget & 74.288 .9 & $100 \%$ \\
\hline LFA & $3,737.9$ & $26.3 \%$ & LFA & $10,891.2$ & $14.7 \%$ \\
\hline $\begin{array}{l}\text { Supplementary area } \\
\text { payments }\end{array}$ & $2,686.2$ & $18.9 \%$ & $\begin{array}{l}\text { Modernization of } \\
\text { agricultural farms }\end{array}$ & $10,219.1$ & $13.8 \%$ \\
\hline $\begin{array}{l}\text { Adaptation of farms to EU } \\
\text { standards }\end{array}$ & $2,501.4$ & $17.6 \%$ & Early retirement & $10,207.3$ & $13.7 \%$ \\
\hline Early retirement & $2,117.7$ & $14.9 \%$ & Agri-environmental & $9,573.0$ & $12.9 \%$ \\
\hline Semi-subsistence farms & $1,350.2$ & $9.5 \%$ & Adding value & $3,510.6$ & $4.7 \%$ \\
\hline $\begin{array}{l}\text { Agri-environmental and } \\
\text { animal welfare }\end{array}$ & 824.3 & $5.8 \%$ & $\begin{array}{l}\text { Semi-subsistence } \\
\text { farms }\end{array}$ & $2,130.2$ & $2.9 \%$ \\
\hline $\begin{array}{l}\text { Total beneficiaries (in } \\
\text { thous.) }\end{array}$ & & 925.95 & $\begin{array}{l}\text { Total beneficiaries } \\
\text { (in thous.) }\end{array}$ & & 1184.14 \\
\hline
\end{tabular}

Source: Own study based (Ministry of Agriculture and Rural Development, 2015; Klepacka, 2009).

When broken down by particular measures, two of them were distinguished in terms of the amount of support (PLN 10.2 billion each) - 'Modernization of farms' and 'Early retirement'. In the first case, almost 58,000 farms received support, and taking into consideration the average amount of payment (over PLN 106,000), it can be concluded that the measure significantly improved the level of equipment of agricultural producers ${ }^{7}$. If we add measures such as 'Increasing the added value to primary agricultural and forestry production' (PLN 3.5 billion) and 'Improvement and development of infrastructure related to development and adaptation of agriculture and forestry' (PLN 2.2 billion), we can evaluate RDP 2007-2013 as a programme intended for increase of competitiveness of the agricultural sector through improvement of effectiveness of management.

On the other hand, 'Early retirement' concerned mostly the obligations for 2004-2006, whereas new contracts covered approximately $17 \%$ of total budget for this purpose. Therefore, the earlier effects of the programme, i.e. change of agricultural structure through

\footnotetext{
${ }^{7}$ It could be mentioned that almost 3,000 farm buildings were modernized or built, as well as 34,000 tractors and 220,000 machines and devices were purchased using these funds.
} 
transfer of land to the benefit of younger and, assumedly, growing farms, were gradually expired. Moreover, 'Support for semi-subsistence farms' was abandoned, whereas the funds paid for this purpose within the framework of RDP in 2007-2013 (PLN billion 2.1) resulted from the obligations of the previous programme. However, new measures were implemented 'Diversification towards non-agricultural activity' and 'Creation and development of microenterprises' (total budget approximately PLN 4 billion), which, in the opinion of the authors, were a more effective support instrument for small farms and did not consolidate the archaic structure of peasant farms. On the other hand, as indicated by I. Nurzyńska (2016), over 26,000 workplaces were created within the framework of these measures, whereas over 15,000 farms diversified their income sources, which, in the opinion of the author, is an insufficient number from the point of view of the so-called redundant workforce in the countryside.

RDP 2007-2013 also included income-generating programme elements. Similarly to the previous perspective, it was 'Support of management in mountain areas and in lessfavored areas (LFA)', which had the largest share in the entire programme budget (PLN 10.9 billion). While modernization activities had a direct impact on the increase of the value of equity capital base of farms, LFA shaped the investment conditions through increase of financial liquidity (it constituted constant income, independent from economy fluctuations, similarly to direct subsidies), and it also covered a significantly higher percentage of farms (over 925,000).

\section{Evaluation of RDP for 2014-2020}

The reform of Common Agricultural Policy for 2014-2020 is the result of negotiations between membership states, where different interests collided. Some of the countries (e.g. Germany and France) strived to continue the existing support mechanisms, with minor changes in direct subsidies (including mainly changes oriented towards their gradual, although incomplete alignment), increased share of CAP second pillar and greater focus on natural environment protection. Other countries (a part of new EU members, including Poland) tried to achieve full convergence with reference to area payments, which were supposed to constitute the most important source of support for agriculture, whereas the instruments of rural development were to be close to the previous financial perspective. Finally, the most far-reaching option (e.g. English, Dutch and Swedish) limited the role of direct support (up to its complete liquidation) in favor of programmes related to environment protection and against climate changes, at the same time transferring a part of tasks from the EU budget to domestic budgets (European Commission, 2011a). Moreover, the common point for reconciliation was the increase of focus on actions related to increasing the position of a farmer in the food chain and risk management. The ultimately adopted solutions combine elements of the first and second party, while rejecting mainly the idea of CAP renationalization. The latter would be hard to accept for the poorer EU membership states not only because they are net beneficiaries of financial flows related to CAP, but also due to the danger of diversification of the support level for the agricultural sector within the framework of a uniform market, and therefore, distortion of competition (Czyżewski, Stępień, 2009). Due to this, EU agricultural policy remained a community policy, although its budget was strictly limited. The cutbacks also affected the Polish party, especially in the field of funds for rural development.

The amount of funds received from the EU budget is one of the criteria of effectiveness for implementation of RDP tasks; therefore, it is worth looking at the specific numbers. And so, in consequence of the arrangements made by the EU leaders in February 2013, Poland was granted support in the amount of EUR 106 billion (at constant prices from 
$2011^{8}$ ), i.e. 4 billion more than in 2007-2013. EUR 72.9 billion is the amount of funds under the cohesion policy, slightly over EUR 18.7 billion are direct subsidies, whereas EUR 9.8 billion was intended for rural development. Therefore, within the framework of Common Agricultural Policy for 2014-2020, Poland received the total amount of approximately PLN 28.5 billion (at constant prices) (http://www.krir.pl/). In comparison with the previous financial perspective, it means an increase by EUR 1.6 billion, whereas the CAP budget for the entire EU is lover by over $11 \%$, including $17.5 \%$ in the first pillar (direct subsidies and market activities). Therefore, can this result be regarded as a success in negotiation of the Polish party? To answer this question, we need to present figures. The increase of funding for Poland results from a higher amount for direct payments. In 2007-2013, we received EUR 13.5 billion for this purpose, whereas EUR 18.74 billion was assumed in the subsequent budget (which means 37\% increase). However, it cannot be overlooked that the amount intended for direct payments in the previous financial perspective was lower due to phasing-in of direct payments (the so-called phasing-in period). Let us remind ourselves that in line with the compromise negotiated at the summit in Athens in 2003, the new membership states were only granted $25 \%$ of the determined payment rate from EU budget in the first year of accession, which would be increased in the following years with a specific amount. In 2007 (the first year of the previous financial perspective), the level of EU budget financing amounted to $40 \%$, and the new membership states did not reach 100\% until 2013 (Czyżewski, Stępien, 2014). Therefore, it is 2013 that should be the basis for calculating the amount of money for 2014-2020 within the framework of the discussed objective. ${ }^{9}$

As regards the CAP second pillar, the amount of EU budget for rural development in Poland is reduced by over 25\% - from EUR 13.4 billion in 2007-2013 to less than EUR 9.8 billion in the current perspective (although EUR 13.5 billion was recorded in the first version of EC budget from 2011). At the same time, a country must reserve at least $30 \%$ of funds in the second pillar for agri-environmental schemes, the obligations resulting from the contracts signed in 2007-2013 amount to EUR 1.36 billion, the reserve for implementation of the 'Investment for growth and jobs' goal is EUR 0.7 billion (i.e. 7\% of European Agricultural Fund for Rural Development, in line with the guidelines of Common Strategic Framework) and resources under Leader programme of EUR 0.5 billion (5\% of RDP). Additionally, a part of funds is transferred from the first to the second pillar (25\% 0 in order to increase the direct subsidies. Therefore, the possibilities for allocation of resources within the framework of Rural Development Programme are very limited.

Even after supplement from the national budget, the amount of RDP budget is approximately EUR 5 billion lower than in the period 2007-2013 (at constant prices; at current prices, the difference amounts to less than EUR 4 billion; compare table no. 4). It is worth mentioning here that with reduced resources for CAP in the total EU budget, the expenses for the second pillar increase in the new financial perspective, which results from a higher involvement of EU agricultural policy in the issues related to modernization of the agricultural sector, development of entrepreneurship in the countryside and natural environment protection. In Poland, the targeting of support on direct subsidies (e.g. through transfer of funds from the second to the first pillar) leads to the assumption that the priority is an increase of transfers (and therefore of income) for farms through the system of area

\footnotetext{
${ }^{8}$ Due to the inflation processes, comparison of amounts from two periods at constant prices has a higher cognitive value.

${ }^{9}$ For Poland, it would be the amount of EUR 3045 million, which multiplied by seven years gives the total amount of EUR 21315 million. In fact, EUR 21.7 billion was recorded in the initial proposal of EC of 2011. Therefore, the result at the level of EUR 18.7 billion is lower than it would result from the principle of maintaining support at the level from 2013 and is the result of cutbacks in the negotiation process.
} 
payments, whereas the issues related to broadly understood countryside development are of secondary importance.

RDP budget for 2007-2013 and 2014-2020 (current prices)

\begin{tabular}{|l|l|}
\hline \multicolumn{1}{|c|}{$\mathbf{2 0 0 7 - 2 0 1 3}$} & \multicolumn{1}{c|}{$\mathbf{2 0 1 4 - 2 0 2 0}$} \\
\hline EU budget = EUR billion 13.4 & UE budget: EUR billion 10.9 \\
National contribution = EUR billion 4 & $\begin{array}{l}\text { Transfer of 25\% to the first pillar: -EUR billion } 2.3 \\
\text { Remaining amount: EUR billion 8.6 } \\
\\
\text { National co-financing: EUR billion 4.9 }\end{array}$ \\
\hline Total: EUR billion 17.4 & Total: EUR billion 13.5 \\
\hline
\end{tabular}

Source: Own work based on (Ministry of Agriculture and Rural Development, 2014).

However, the limited RDP budget is to be additionally financed through the cohesion policy with the amount of EUR 5.2 billion. A question arises whether the additional funds will compensate the decline resulting from the reduction of EU funds, as well as its partial reallocation from the second to the first pillar. The reference point should be the division of funds between the urban and rural areas in the previous budget periods. And so, in 2004-2006 (i.e. incomplete budget period), approximately $10 \%$ of financial resources within the framework of structural funds and cohesion policy (EUR 1.3 billion) was intended for financing projects directed towards the rural development. In 2007-2013, this share increased to $15 \%$ (i.e. almost EUR 13 billion). Moreover, approximately $60 \%$ of funds were intended for activities which impact both rural and urban areas, whereas the adopted level of EUR 5.2 billion is only slightly over 6\% of the total cohesion policy budget (FUNDEKO, 2011; Stec, 2011). In such case, it is difficult to talk about an increase of support for rural areas, both as a percentage and in absolute terms.

Table 5

List of actions within the framework of RDP for 2014-2020

\begin{tabular}{|ll|l|}
\hline \multicolumn{1}{|c|}{ Priority } & \multicolumn{1}{c|}{ Actions } \\
\hline 1. & Transfer of knowledge & $\begin{array}{l}\text { Presentation of model farms, advice and financing professional } \\
\text { trainings for advisers, cooperation between entities which } \\
\text { implement progress }\end{array}$ \\
\hline $\begin{array}{l}\text { 2. } \\
\text { Increase of } \\
\text { competitiveness }\end{array}$ & $\begin{array}{l}\text { Modernization and restructuring of farms, bonuses for young } \\
\text { farmers }\end{array}$ \\
\hline 3. $\begin{array}{l}\text { Food chain and risk } \\
\text { management }\end{array}$ & $\begin{array}{l}\text { Subsidies for groups implementing quality systems, support for } \\
\text { processors, creation of groups of agricultural producers, support } \\
\text { for fundamental services and restoration of agricultural potential }\end{array}$ \\
\hline 4. & Support for & $\begin{array}{l}\text { Support for agri-environmental-climate schemes, support for } \\
\text { ecological farms, for farms within Natura 2000 sites and in less- } \\
\text { favored areas }\end{array}$ \\
\hline 5. & Resource management & Afforestation \\
\hline 6. & Fight against poverty \\
and social exclusion & $\begin{array}{l}\text { Bonuses for beginning non-agricultural activity, support for } \\
\text { development of entrepreneurship, construction of local roads, } \\
\text { Leader programme }\end{array}$ \\
\hline
\end{tabular}

Source: Own work based on (Ministry of Agriculture and Rural Development, 2013a).

As regards the planned measures for 2014-2020, the priorities (at the EU level) are as follows (Ministry of Agriculture and Rural Development, 2013b): 
- accelerated transfer of knowledge and innovation;

- increase of competitiveness and profitability of farms;

- efficient functioning of food chain and risk management;

- renovation, support and protection of ecosystems;

resilient economy;

- effective resource management, transition to low-carbon and climate change

- fight against poverty and social exclusion, economic development of rural areas.

At the same time, the formula of multiannual programmes, co-financed from the domestic funds, is maintained, with higher flexibility of particular regions in selection of priorities (European Commission, 2011b). The local authorities will decide about the division of funds to a bigger extent than before. In Poland, in practice the Rural Development Programme is to be a continuation of the previous activities (the list was presented in Table 5). It is worth emphasizing that under priority 4 'Support of ecosystem', the foreseen measures will have to go beyond the 'greening' standards ${ }^{10}$ under the first pillar, in order to avoid a situation in which a farmer receives both 'green' payment and support under the second pillar for the same activity (Czyżewski, Stępień, 2015).

Polish RDP budget was structured in a manner which prefers modernization of agriculture and increase of its competitiveness (compare E. Kiryluk-Dryjska 2014). This is evidenced e.g. by the increase of expenses (both in nominal and real terms) intended for investments in tangible assets and functioning of groups of agricultural producers, as well as 'young farmer' (only in nominal terms here). Such activities will definitely contribute to modernization of the agricultural sector. Overall, the amount of over EUR 4.3 billion was reserved for competitiveness of agriculture in the second pillar. Only slightly less - EUR 4.2 billion is to be spent on the agri-environmental-climate scheme (somehow out of necessity), which results from the universally adapted principle of using minimum $30 \%$ of the second pillar for this purpose. However, over half of this amount (EUR 2.3 billion) is composed of payments for areas with natural handicaps (LFA), which in fact are supplements of area subsidies and play a passive role in actions to the benefit of the natural environment (and which would have to be launched).

Other resources in this area are much lower than in 2007-2013, despite the declared 'ecologization' of EU agricultural policy. Particularly striking is the lack of sufficient funds for supporting systems for managing water resources, due to the increasingly frequent rainfall deficits, especially in late spring and summer. There is also a risk of lower efficiency of the goal as a result of introducing support degressivity. The significant decrease of financing is also visible in case of tasks related to the development of entrepreneurship and nonagricultural workplaces (former 'diversification of activity') and 'microenterprise', currently 'bonuses for beginning business activity') and development of infrastructure ('fundamental services, renovation and development of countryside'; compare Table 6). Although support of these activities under cohesion policy is planned, the proposed level of allocation of resources is lower than in the previous years.

To conclude, with reference to allocation of resources for particular measures, regions with well-developed agriculture are preferred. This is demonstrated through a relatively high amount of budget for pro-investment and modernization activities of farms and certain marginalization of activities related to the development of infrastructure of rural areas and entrepreneurship. Such goal structure may increase the competitiveness of farms from

\footnotetext{
10 'Greening' of direct subsidies concerns a part of the total payment (30\%), which depends on the fulfilment of the following requirements by the farmer: diversification of crops, maintenance of permanent pasture and exclusion of a part of land for the so-called pro-ecological areas. However, these requirements do not cover the smallest farms (under 10 or 15 ha AA).
} 
provinces in the western and central Poland (Wielkopolska, Kujawy-Pomerania and Mazovia Provinces), but also lead to further reduction of agriculture in south-eastern Poland. Regionalization as such is not necessarily wrong, if agriculturally weaker areas are provided with an alternative development direction. It means that specific endogenic resources of a particular area should be taken into consideration in the rural development processes and used more efficiently (Kołodziejczyk, 2015). However, it is difficult to notice such approach in RDP 2014-2020.

Table 6

Comparison between RDP action budgets for 2007-2013 and 2014-2020

\begin{tabular}{|c|c|c|c|}
\hline Action & $\begin{array}{l}\text { 2007-2013 } \\
\text { (in EUR million, } \\
\text { current prices) }\end{array}$ & $\begin{array}{l}\text { 2014-2020 } \\
\text { (in EUR million, } \\
\text { current prices) }\end{array}$ & $\begin{array}{l}\text { 2014-2020 } \\
\text { (in EUR million, } \\
\text { constant prices) }\end{array}$ \\
\hline Modernization of farms & 2489 & 2816 & 2532 \\
\hline 'Young Farmer' & 581 & 585 & 526 \\
\hline Producer groups & 183 & 353 & 317 \\
\hline $\begin{array}{l}\text { Restoration of agricultural } \\
\text { production potential }\end{array}$ & 197 & 415 & 373 \\
\hline Less Favoured Areas (LFA) & 2367 & 2330 & 2095 \\
\hline $\begin{array}{l}\text { Agri-environmental scheme/ } \\
\text { agri-environmental and } \\
\text { climate + ecological }\end{array}$ & 2307 & 1760 & 1582 \\
\hline $\begin{array}{l}\text { Afforestation + restoring } \\
\text { potential/ Afforestation }\end{array}$ & 361 & 301 & 271 \\
\hline $\begin{array}{l}\text { Diversification }+ \\
\text { microenterprises/ Bonuses for } \\
\text { beginning business activity. }\end{array}$ & 1041 & 414 & 372 \\
\hline $\begin{array}{l}\text { Fundamental services, } \\
\text { renovation and development } \\
\text { of countryside }\end{array}$ & 2304 & 1075 & 967 \\
\hline LEADER & 801 & 735 & 661 \\
\hline
\end{tabular}

Source: Own study based on (Ministry of Agriculture and Rural Development, 2015; Ministry of Agriculture and Rural Development, 2014).

\section{Conclusions}

For at least two decades, Polish agriculture has been subject to some processes whose direction and dynamics should be evaluated positively, as well as such others that maintain certain negative features and structures. Integration with the European Union allowed to compensate for certain arrears and, from the perspective of several years, it can be regarded as the most important source of development of food economy. The cumulative effects of Common Agricultural Policy led to significant improvement of income situation of agricultural producers and structural changes at the level of farms. Additional development impulses concerned not only agriculture, but also the entire countryside, thanks to which in 
many aspects it is close to the level of cities (Wilkin, 2016). The creation of Rural Development Programme as an element of Common Agricultural Policy particularly launched the multiplier effects of investment expenses. Through the purchase of new machines and devices, construction or renovation of farm buildings under modernization programmes, the effectiveness of use of production factors (mainly labor and land) is now higher, whereas the distance between Polish and western European farms is not as big as before. Income support, for instance in the form of funds for less-favored areas (and before also supplementary payments) became a significant accelerator for the processes of innovation, modernization and structural changes in the countryside. The RDP financial envelope (including early retirement) was intended for the expected transformations of agricultural structure, although this process occurs slowly. Finally a part of the funds was used for reduction of excessive employment in the agricultural sector (diversification of activities, development of microenterprises).

In the opinion of the authors, the positively evaluated changes are accompanied by two major weaknesses. First of all, investment processes are carried out by a limited number of most frequently economically strongest agricultural producers. The effect is mainly an increase of potential of developing farms, whereas the average and poor farms grow to a significantly smaller extent. Although discontinuance of agricultural activity is an inevitable process, it is important that it should occur along with changes in the number and structure of farms. In this context, particularly visible is still the lack of sufficient amount of measures related to the support of entrepreneurship in rural areas and for the labor market (subsidies for creation of non-agricultural activity, professional activation, support of education system and increase of access to IT technologies. Secondly, in case of developing farms, not only modernization support is important, but also creation of a system which guarantees stable income from agricultural production. In Polish RDP, price or income risk management is still limited to declarations only rather than actual solutions.

\section{References}

1. Bear-Nawrocka A., Poczta W., 2016. Polskie rolnictwo na tle Unii Europejskiej, [w:] Polska wieś 2016. Raport o stanie wsi (edited by J. Wilkin, I. Nurzyńska). Warsaw, Wyd. Naukowe Scholar, pp. 85, 98.

2. Căpuşneanu S., Ivan R., Topor D.I., Oprea D.M., Muntean A., 2015. Environmental Changes and their Influences on Performance of a Company by Using Ecodashboard, Journal of Environmental Protection and Ecology 16, No. 3, pp. 10911100.

3. Central Statistical Office in Poland, 2011. Report on results. General Agricultural Census 2010. Warsaw.

4. Central Statistical Office in Poland, 2016. Statistical Yearbook of Agriculture 2016. Warsaw.

5. Central Statistical Office in Poland, 2017. Land use and sown area in 2016. Warsaw.

6. Czubak W., Sadowski A.: Dostępność informacji oraz czynniki utrudniające ubieganie się o dopłaty bezpośrednie, Wieś i Rolnictwo 3/2011, pp. 138-155.

7. Czyżewski A., Stępień S., 2014. Fundusze unijne dla Polski i polskiego sektora rolnego w perspektywie 2014-2020, Zeszyty Naukowe Szkoły Głównej Gospodarstwa Wiejskiego (SGGW) w Warszawie: Polityki Europejskie, Finanse i Marketing, No. 11(60), pp. 34-45.

8. Czyżewski A., Stępień S., 2015. Wspólna Polityka Rolna (WPR) Unii Europejskiej po 2014 roku z polskiej perspektywy. [In:] Problemy rozwoju rolnictwa $i$ gospodarki żywnościowej w pierwszej dekadzie członkostwa Polski w Unii Europejskiej (edited by 
A. Czyżewski, B. Klepacki). Warsaw, Polskie Towarzystwo Ekonomiczne, pp. 229252.

9. Czyżewski A., Stępień S., 2009. Zmiany mechanizmów Wspólnej Polityki Rolnej UE a oczekiwania Polski, Ekonomista, No. 4, pp. 451-452.

10. European Commission, 2011a. Assessment of the impact of the CAP until 2020 project (typescript). Brussels.

11. European Commission, 2011b. The CAP Reform - an explanation of the main elements. MEMO/11/685. Brussels.

12. Eurostat, website: http://ec.europa.eu/eurostat/data/database (access date: 12.09.2017)

13. FUNDEKO, 2011. Wplyw wspólnej polityki rolnej i polityki spójności na rozwój obszarów wiejskich, Warsaw.

14. http://www.krir.pl/2014-01-03-03-24-03/pozostale/2020-przywodcy-pastw-uewynegocjowali-qbudet-rolnyq-na-lata-2014-2020 (access date: 21.09.2017).

15. Kiryluk-Dryjska E., 2014. Allocation of financial resources for selected RDP activities 2014-2020 with the use of linear optimization, Journal of Agribusiness and Rural Development, No. 3(33), pp. 61-73

16. Klepacka W. (editor), 2009. Wyniki wdrażania Planu Rozwoju Obszarów Wiejskich na lata 2004-2006. Warsaw, ABC - Zakład Poligraficzny.

17. Kołodziejczyk D. (editor), 2015. Wieloaspektowe ujęcie problemu spójności obszarów wiejskich na poziomie lokalnym $i$ regionalnym $w$ dotychczas realizowanych $i$ planowanych strategiach rozwoju. Warsaw, Instytut Ekonomiki Rolnictwa i Gospodarki Żywnościowej.

18. Łykowski P., 2015. 10 lat wspólnej polityki rolnej w Polsce. 20 lat działalności ARiMR. Sielinko, Ośrodek Doradztwa Rolniczego.

19. Ministry of Agriculture and Rural Development, 2013a. Preliminary outline of the Rural Development Program 2014-2020. Warsaw.

20. Ministry of Agriculture and Rural Development, 2013b. Status of work on the assumptions of the Rural Development Program 2014-2020. Warsaw.

21. Ministry of Agriculture and Rural Development, 2014. Rural Development Program for 2014-2020 (RDP 2014-2020). Warsaw.

22. Ministry of Agriculture and Rural Development, 2015. Cumulative report on the implementation of the Rural Development Program for the years 2007-2013 cumulatively since the Program was launched on 31 December 2015. Warsaw.

23. Nurzyńska I., 2016. Polska wieś $i$ rolnictwo jako beneficjenci funduszy Unii Europejskiej. [In:] Polska wieś 2016. Raport o stanie wsi (edited by J. Wilkin, I. Nurzyńska). Warsaw, Wyd. Naukowe Scholar, pp. 120-124.

24. Sadowski D., Baer-Nawrocka A., Poczta W., 2013. Gospodarstwa rolne w Polsce na tle gospodarstw Unii Europejskiej - wptyw WPR. Warsaw, Central Statistical Office in Poland, p. 7.

25. Stec M, 2011. Znaczenie funduszy pomocowych Unii Europejskiej dla spójności społeczno-gospodarczej polskich regionów, Nierówności Społeczne a Wzrost Gospodarczy, No. 18, pp. 174-183.

26. Wilkin J., 2016. Polska wieś na tle kraju i Europy - synteza raportu. [In] Polska wieś 2016. Raport o stanie wsi (edited by J. Wilkin, I. Nurzyńska). Warsaw, Wyd. Naukowe Scholar, pp. 120-124. 